

J. Environ. Sci. \& Natural Resources, 5(1): 151 - 158, 2012

ISSN 1999-7361

\title{
Prospects and Constraints of Madhupur National Park Management
}

\author{
M. Y. Mia, M. U. Hossain and S. Farzana \\ Department of Environmental Science and Resource Management \\ Mawlana Bhashani Science and Technology University, Santosh, Tangail
}

\begin{abstract}
The study was conducted in Madhupur National Park (MNP), which is very well known for its characteristics as deciduous forest. This study examined the constraints of park management, causes of deforestation and prospects of Madhupur Sal forests of Bangladesh. Data were collected from the Madhupur National Park authority and a study was done to have clear scenario of the park management and status of forest over time. It is evident from the study that due to various factors like anthropogenic disturbances, political abusement, absence of proper rules and regulations, willingless of the authority, encroachment of forest by locals/local leaders, illegal cutting of Sal trees, agro-forestry, and lack of adequate budget are main constraints for managing MNP. The study also revealed that about $1-3 \%$ of the forest is depleted each year, and about 50-80 years later, the forest will be completely vanished or scattered in somewhere. However, MNP will be a sustainable reserve forest for Sal trees and other flora and fauna, and also be a potential ecotourism spot, if it is properly managed. Findings of the study will help to identify the prospects and constraints of MNP and also in other National Parks in Bangladesh which ultimately conserve the biodiversity and help to maintain natural balance.
\end{abstract}

Keywords: Constraints, Madhupur National Park, Management, Prospects

\section{Introduction}

Forestry contributes two percent to the Gross Domestic Product of Bangladesh (BBS, 2006). Madhupur forest is a tropical, moist, and deciduous type of forest. MNP is located at $24^{0} 45^{\prime} \mathrm{N}$ Latitude and $90^{\circ} 05^{\prime} \mathrm{E}$ Longitude, on the Tangail-Mymensingh main road, encompass a Gazette notified area of 8,436 ha. and is under the territorial jurisdiction of Tangail Forest Division (Fig. 1). Actually, this forest is present in low land and flood plain based area. In our country, only this forest contains pure Sal (Shoria robusta) tree.

The Park was established by the Forest Department in 1962 and formally notified in Gazette in 1982. At present, the tract of Madhupur forest (MF) consists an area of 45,565.18 acres out of which 2,525 acres are reserved and 4,304 acres land are under the process to be declared as reserved forest. For the purpose of biodiversity conservation, Government declared Madhupur Garh which is also known as 'Madhupur National Park' comprising an area of 20,837.23 acres by a gazette, notifying on $24^{\text {th }}$ February 1982 . Out of that, 20,244.23 acres are under Madhupur upazila of Tangail district and 593.00 acres are under Muktagacha upazila of Mymensingh district (Ahmed, 2008).

The natural and climatic condition of this region is very much suitable for growing pure Sal tree. Besides, this forest contains a huge variety of floral composition, different type of mammals, reptiles, avis and amphibians. The major part of this forest is covered with Sal tree. It houses a total of 176 species of plants including 73 trees, 22 shrubs, 1 palm, 8 grasses, 27 climbers and 45 herbs. Besides, there are a number of exotic species planted in the national park area. Existing faunal composition includes 21 species of mammals, 140 species of birds and 29 reptiles in this park (Gain, 2004). In Bangladesh, there is a chronic trend of declining natural forest habitat and the rate of forest degradation has accelerated in the past 30 years. The average annual rate of deforestation in Bangladesh is between three and four percent, while the South Asia average is only 0.8 percent (Rasheed, 2008). Forest also generates employment and income as well as facilitates of ecotourism (Gain, 2002). Encroachment is an important cause of deforestation and forest degradation in Bangladesh. They show that the illicit felling is done by the poor villagers, who usually work for the illegal traders, local influential leaders and forest land encroachers. The main cause of depletion of Sal forest was due to the land clearance for agriculture and forestland encroachment. The almost half of the total Sal forest has been already depleted (Iftekhar and Hoque, 2005). If the forest is not degraded, it would be an important ecotourism spot and source of revenue income of the Government.

Keeping the above points into consideration the study was done to know the park management system and, to identify the constraints and prospects of it. 


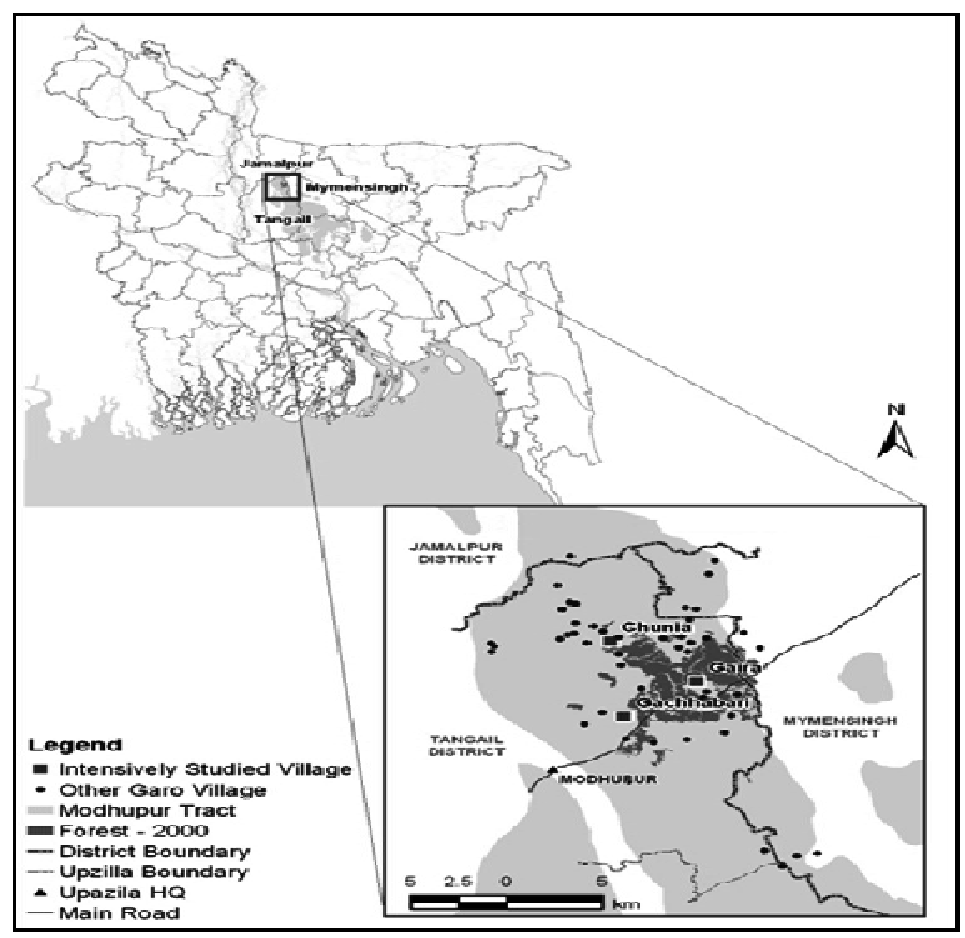

Fig. 1. Study area in Madhupur National Park. (Source: Dey, 2007).

\section{Methodology}

The study was done mainly based on primary and secondary information. Different methodologies such as- interview with local people, questionnaire survey, FGD and PRA were used to identify the problems and prospects for park management. Primary data about the constraints of park management were collected from the field level staff are the intrinsic study, the secondary data were collected from the management authority and related literatures. The electronic and web based information were also used for data collection. Geographic Information System (GIS) with Arcview (3.2) and Google earth software were used to show the present scenario of the park and Adobe Photoshop was used to prepare the proposed management system of Madhupur National Park.

\section{Results and Discussion}

\section{Present management system}

At present the management system of MNP is very simple. It is divided into four Ranges and nine Bits. Four Ranges are: i. Central National Park Range, ii. Dokhola Range, iii. Madhupur Range, and iv.
Arankhola Range. There are four Bits under the Central National Park Range such as Sadar, Rajabari, Beribadh, and Lahuria Bit. Two bits namely, Dokhola Sadar and Chandpur Bit are under Dokhola Range. Madhupur Range contains two bits such as Charaljani and Mahishmara Bit, and Arankhola Range contains only one bit such as Arankhola.

\section{Temporal and spatial conditions of MNP}

The commercialization process of MNP became more rapid through the introduction of pineapple cultivation into the area. At present, most of the forestland in Madhupur has been denuded, degraded or encroached upon or taken over for the commercial production of pineapples, bananas, the industrial plantation of rubber and exotic fuel-wood species (Gain, 2004). Madhupur forest was a densely and compact forest, even in the 1960s. After that, the forest area was decreasing $1-3 \%$ per year. It is assumed that if the decreasing rate is going on in same manner the forest will be completely vanished after 50-80 years. The Forest conditions from 1962 to 2003 (1962, 1977, 1997, 2002, and 2003 through satellite images) is shown in Fig. 2. and Fig. 3. 


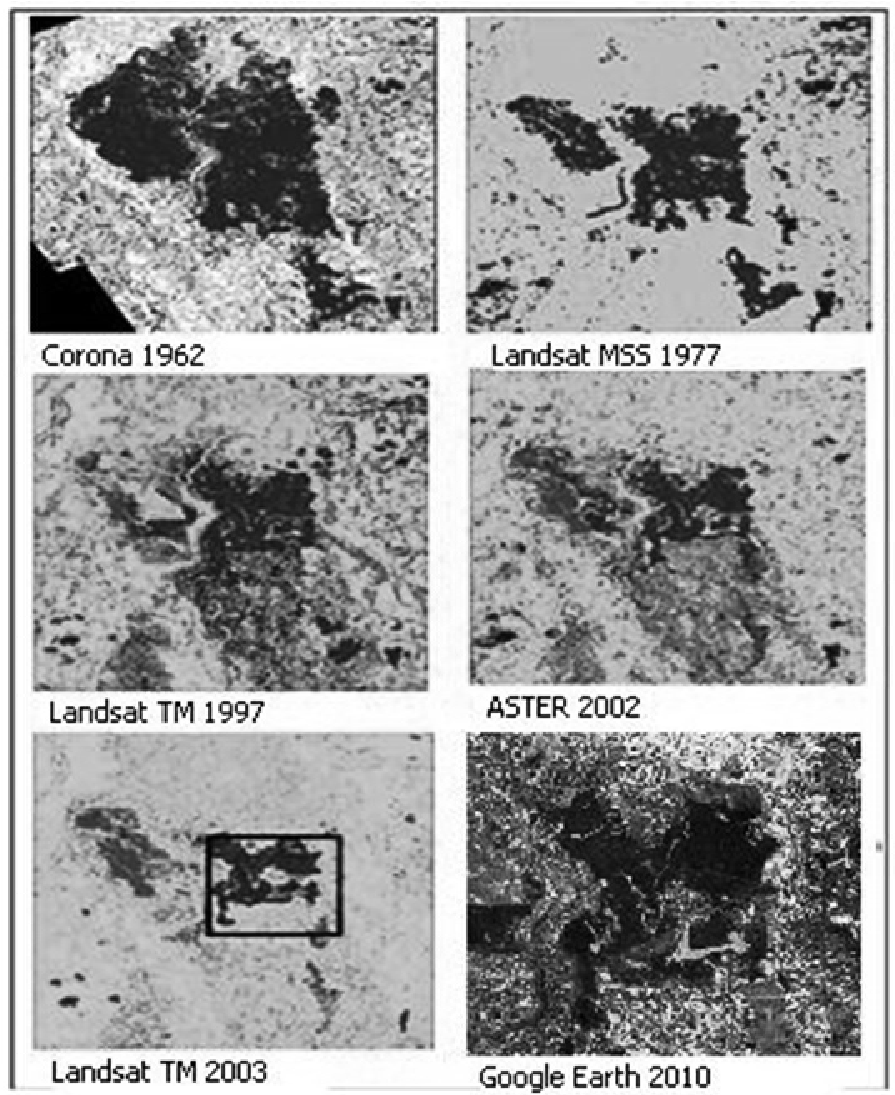

Fig. 2. The conditions of MNP from 1962 to 2010

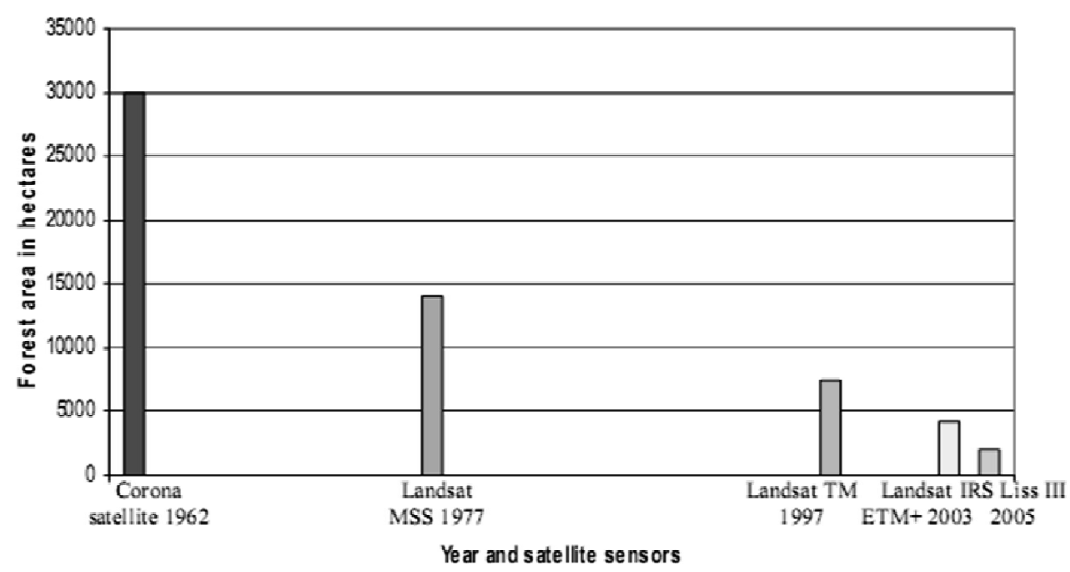

Fig. 3. Declination of Madhupur forest area from 1962-2005 (Source : Islam, 2007).

\section{Causes of depletion and degradation of MNP}

The scenario of the Sal forest was quite good few years back. But at present the forest faces a miserable condition. More and more land of the degraded forest is being used for commercial agricultural production. Presently, around 62 thousand hectares of land of MNP have been used for banana cultivation (Dey, 2007). The study revealed that, there were many reasons for depletion of the resources and in park management such as- i) anthropogenic disturbance, ii) climatologically change, iii) absence to proper rules and regulations, iv) absence adequate budget, v) human settlement, 
vi) logging, vii) agricultural activities, viii) cattle ranching, ix) fragmentation of forest land by road construction, $\mathrm{x}$ ) brick field and saw mills, xi) activities of Garo tribal, xii) existing population pressure, xiii) encroachment etc, (Fig. 4).
According to the Forest Division of Tangail region, about half of its total area is occupied or encroached by the local people. Encroached and occupied area of four Ranges in Madhupur National Park is shown in Table 1.

Table 1. Encroached forest area in various Ranges in Madhupur National Park.

\begin{tabular}{|l|l|l|l|l|l|l|}
\hline \multirow{2}{*}{ Range } & \multicolumn{3}{|c|}{ Encroached forest area in Acres } & \multicolumn{1}{c|}{$\begin{array}{c}\text { Encroached forest area in Acres (According to record } \\
\text { book) }\end{array}$} \\
\cline { 2 - 6 } & Garo & Bangali & Total & \multicolumn{2}{c|}{ Garo } & Bangali \\
\hline Dokhola & 3700.46 & 7748.16 & 11448.62 & 284.55 & 1085.56 \\
\hline Central National Park & 2247.78 & 1571.82 & 3819.60 & 152.88 & 232.55 \\
\hline Madhupur & 461.92 & 3476.29 & 3938.21 & 3.00 & 273.93 \\
\hline Arankhola & 301.72 & 1709.20 & 2010.92 & 18.37 & 298.22 \\
\hline
\end{tabular}

Source: BELA, 2007; Rahman and Kamruzzaman, 2009

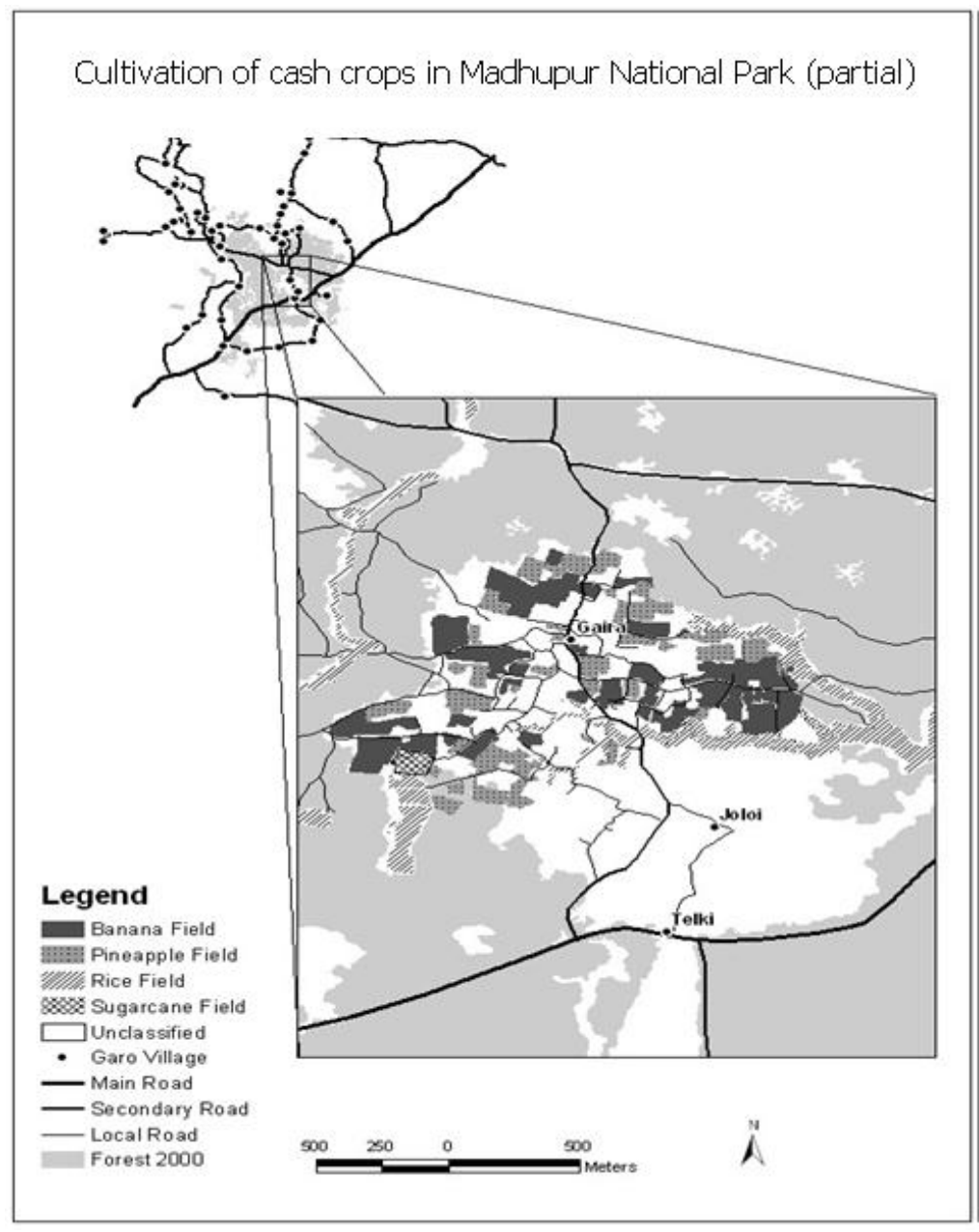

Fig. 4. Land-use pattern in Madhupur National Park (partial). Source: Dey, 2007. 


\section{Main constraints for management in MNP}

The present study identified several main constraints for the management of MNP which are-i) movements of indigenous peoples against the implementation of National Park principles (Fig. 5), ii) failure of law and enforcement to ban the Banana and Pineapple garden in MNP (Fig. 6), iii) political influences for Banana and Pineapple gardening in MNP, iv) willing less of Government to protect the Park, v) encroachment of forest and land by locals and local leaders, vii) illegal cutting of Sal trees under political power, viii) less or no security for the management people and the forest, ix) misuse of politics to management people, $x$ ) less or no scope to implement the management strategy. The present study is also in conformity with the findings of Iftekhar and Hoque, (2005). They mentioned that forest management has caused deforestation through corruption of local elites, members of political parties and police department, non recognition of land right, corruption of administration, irresponsibility of Forest Department officials, discriminatory social system, agricultural practices, inappropriate Jhumming, over population, poverty and unemployment.



Fig. 5. Movement of indigenous people to stop the National Park.

( Source: TOJO Bunpei, 2005).


Fig. 6. Conversion of forest by Banana and Pineapple garden in MNP.

(Source: Researchers $\square$ photograph, 2011).

\section{Park management techniques and prospects}

The modern concept of park management is no more than the combination of the two ancient principles, namely- i) the need to plan resource management, and ii) the need to take protective measures to ensure that resources do not become exhausted. 
Forest Department has considered three kinds of a ctivities in order to maintain protection and conservati on of biodiversity in Protected Areas, these are, (i) buffer zone plantations, (ii) core area protection, and (iii) extension of protected areas and declaring ne $\mathrm{w}$ areas where possible.
To stop the deforestation, and to overcome the constraints of forest management and to protect the park following proposed model may be considered. According to the model, MNP may be divided into several zones, which are given in Fig. 7.

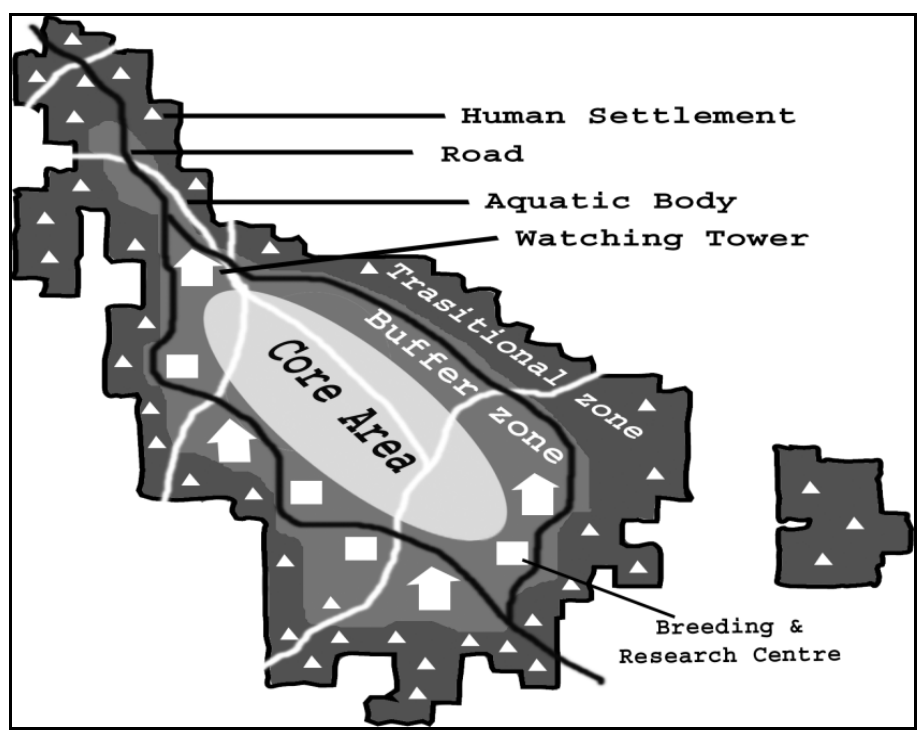

Fig.7. Proposed model for the management of MNP (partialy)

\section{Core area}

Core or restricted area is the inner most part of a park where wildlife including plants would be conserved. This area could serves as the breeding ground for wildlife and strictly restricted to human interferences even management in which the nature should be allowed to grownup naturally. This area (approximately 3000 acre) should be preserved by establishing a sustainable wall, inside where nobody, even forest department officials are not allowed to enter. If it is done, the core area of Madhupur forest will sustain as a natural forest after $50-100$ years or more.

\section{Buffer area}

It usually surrounds and adjoins the management zones within which the sustainable use of natural resources will be permitted. The activities in buffer zones usually include lodging and restaurants for the tourists, small garden zones, using traditional methods on collecting fallen timber, harvesting fruits, seasonal grazing of domestic stock and cutting of bamboo or grass. Activities forbidden in buffer zones generally include burning vegetation, cutting live trees, constructing buildings, and establishing plantation. This can be divided in two zones-
Multiple Use Zone: This zone can be used by the forest staff for the multiple purposes.

Recreational Zone or ecotourism area This zone may be used for recreational purpose for the visitors for observing the natural beauty of the forest in the natural environment without hampering the forest component.

\section{Transitional and settlement area}

Outer zones within which various settlement such as villages or as cluster villages, agricultural activities, local vendors and markets, hotels, and other uses and in which local communities, management agencies, NGOs, cultural groups, economic interests, and other stakeholders work together to manage and create sustainable develop of resources of the areas.

\section{'P' theory for the management of MNP}

For the effective management of any protected area the ' $\mathrm{P}$ ' theory may be considered. The ' $\mathrm{P}$ ' theory is involved with 4Ps which includes-P1= Problems, P2 $=$ Processes, $\mathrm{P} 3=$ Progress and $\mathrm{P} 4=$ Prospects. First 3Ps is the cause and final $\mathrm{P}$ is results. $\mathrm{P} 1$ involves identifying all possible sorts of exterior, interior and 
associated problems in the protected area. For solving the problems, mitigating impacts and improving the present status, the possible management approaches and strategies are to be taken which is involved in P2. For the assessment of improvement over time due to management, the continuous monitoring of management practices and to identify the problems arising during management should be involved in P3. The result of $\mathrm{P} 4$ will arise for the successful carryout of first 3Ps. Considerations for the management of MNP with ' $\mathrm{P}$ ' theory is given in Fig. 8.



Fig. 8. 'P' theory associated with the management MNP.

\section{Conclusions and Recommendations}

Ecologist categorized the causes of deforestation into two groups: (a) Greed and the relentless pursuit of economic growth and (b) population growth. In Bangladesh the major factors of deforestation are (a) Population Explosion, (b)
Settlement and Urbanization and (c) Management Practices (Haque, 2006). Nowadays, among many cash crops, the production of bananas and pineapple has raised many questions among the environmentconscious people. They fear that this will destroy the forest ecosystem because of forest encroachment and excessive use of agrochemicals in the long run. The 
study shows that the main hindrance in the path of protecting the forest is the shortage of the workforce and the logistics along with the link-up of some corrupt forest officials with the encroachers. The people having strong political connection and with the help of forged documents has grabbed the vast forest area of the region. Moreover, the socioeconomic consequences of a commercial economy need to be given very serious consideration.

It is recommended that initiatives from both the government and non-government sectors should be undertaken in order to monitor the effects and management constraints of this area. Following suggestions may be adopted for the conservation and management of the park: i) Develop and implement policies conducive to improved forest area management and strengthen the institutional systems and capacity of the Forest Department and key stakeholders so that improvements under the project can be constituencies to further assess the policy goals, ii) Integrate indigenous people into the management sectors, iii) The plantation of exotic species harmful to the original species should be stopped, iv) Cultivation of Banana and Pineapple should be sited outside of the buffer zone but allow only under the management, v) Wall, trekking, road etc. of eco-park should be constructed under management, vi) Design and implement a program of habitat management and restoration for forest areas, vii) Integrate the livelihood patterns of indigenous people into the Park Management, viii) Extension and development of existing Park Management, ix) Creation and Recreation facilities in the buffer zone, $\mathrm{x})$ Improvement and extension of animal breeding center, xi) Reforestation upon fallow land, xii) Increase opportunities for ecotourism, education and research under rules and regulations.

It can be concluded from the present study, if the MNP is brought under proper management through applying the above suggestions, the park will exist with its natural beauty and resource. Moreover, an ecotourism spot can be initiated inside the park which will be used as recreational purpose as well as a source of revenue earnings of the government. If so, it will create an employment generation for the huge number of indigenous people and people from the other parts of the country.

\section{References}

Ahmad, A.I. 2008. Underlying causes of deforestation and forest degradation in Bangladesh. Institute of Cultural affairs (ICA), Bangladesh, pp. 6-21 .

BBS (Bangladesh Bureau of Statistics)., 2006. Statistical Year Book of Bangladesh, Statistics Division, Ministry of Planning, Government Republic of Bangladesh.

BELA (Bangladesh Environmental Lawyers Association), Briefing Paper, 2007.

Dey, S., 2007. The commercialisation of the indigenous economy and its impact on the environment of Modhupur Garh, Bangladesh, Int. J. Green Economics, Vol. 1, Nos. 3/4, pp.465-477.

Gain, P. 2002. Bangladesh Environment Facing the $21^{\text {st }}$ Centaury $\left(2^{\text {nd }}\right.$ edition), Published by the Society for Environment and Human Development (SHED), Dhaka.

Gain, P., 2004. Modhupur Forest. Demise Is ImminenU, Society for Environment and Human Development (SEHD).

Haque, Z. 2006. Tree plantation for a green Bangladesh, Ministry of Foreign Affairs, Government of the People's Republic Bangladesh, published by External Publicity Wing, 3p.

Iftekhar, M. S and Hoque, A. K. F. 2005. Causes of Forest Encroachment: An Analysis of Bangladesh. Geo Journal 62, (1 -2) (Netherlands: Springer).

Islam, S. T. 2007. Resource Assessment of Deciduous Sal Forests in Bangladesh. PhD Thesis, Geography Department, Durham Univers ity, Durham (UK).

Rahman, M. A. and Kamruzzaman, M., 2009. Corruption, Environmental Crime and Deforestation in Bangladesh: The Case of Madhupur Sal Forest. Deforestation and Forest Degradation in Bangladesh, published by ICABangladesh. 96p.

Rasheed, K. B. S., 2008. Bangladesh- Resource and Environmental profile, published by $\mathrm{A} \mathrm{H}$ Development publishing House, Dhaka, 103 p.

TOJO, Bunpei (Division of Asian Area Studies). 2005. Deforestation Discourse and Land Tenure Conflict in the Madhupur Forest Area, Bangladesh. 